\title{
Na-K-Cl Cotransporter-1 as a Regulator of Manganese-induced Astrocyte Swelling
}

\author{
Ramakrishnan $\mathrm{R}^{1 *}$, Raghavendra $\mathrm{HL}^{1}$, Krishnan Prabhakaran ${ }^{2}$, \\ Anumantha G. Kanthasamy ${ }^{3}$, Shivaleela P. Upashe ${ }^{1}$ and Fekadu Beyene ${ }^{4}$ \\ ${ }^{1}$ College of Health and Medical Sciences, Wollega University, Post Box No: 395 Nekemte, Ethiopia \\ ${ }^{2}$ Department of Pharmacy and Health Professions, Elizabeth City State University, Elizabeth City, \\ North Carolina 27909, USA \\ ${ }^{3}$ Department of Biomedical Sciences, 2062 Veterinary Medicine Building, lowa State University \\ Ames, lowa 50011-1250, USA \\ ${ }^{4}$ Department of Nutrition and Food Science, College of Engineering and Technology, Wollega University, \\ Post Box No: 395, Nekemte, Ethiopia
}

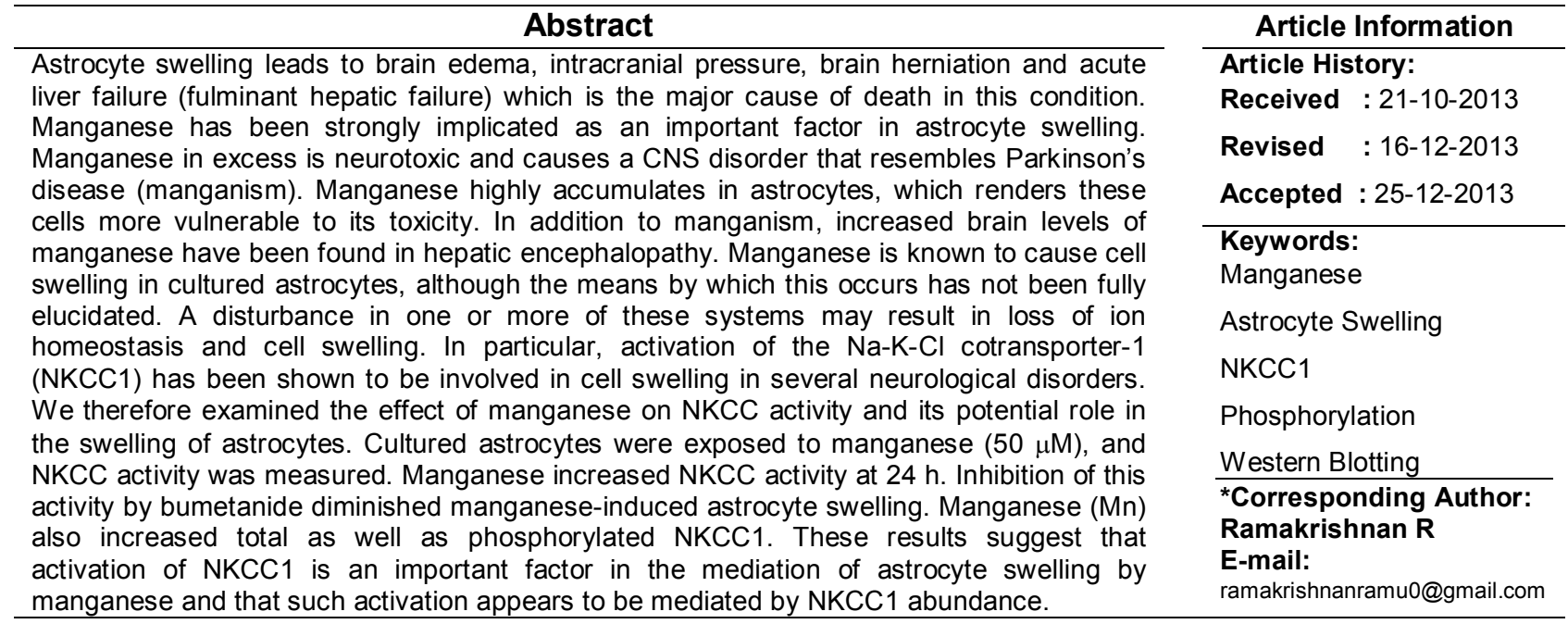

\section{INTRODUCTION}

Acute liver failure (fulminent hepatic failure) is associated with cerebral edema, increased intracranial pressure, herniation, and death (Vaquero et al., 2003). Although the pathogenetic mechanisms for brain edema are still not clear, manganese has been strongly implicated as an important etiological factor (Rama Rao et al., 2007), and astrocyte swelling has been implicated as a major process responsible for the edema (cytotoxic edema) (Martinez, 1968; Norenberg, 1977; Norenberg, 2001; Traber et al., 1989). Mechanisms mediating the astrocyte swelling and the subsequent brain edema in fulminant hepatic failure remain poorly understood.

Manganese is an essential trace metal and is an integral component of key enzymes such as glutamine synthetase (Wedler et al., 1982) and mitochondrial superoxide dismutase (McCard, 1976). However, excess deposition of manganese in the CNS leads to neurological abnormalities (manganism) which is associated with astrocyte swelling (Rama Rao et al., 2007). Manganese in the brain is preferentially deposited in astrocytes because of the presence of high capacity transporters in these cells (Aschner et al., 1992; Aschner et al., 1999). Such preferential accumulation suggests that astrocytes may be more vulnerable to manganese toxicity than other neural cells. Consistent with this possibility, primate models of manganese toxicity have shown astrocytic pathological alterations (Olanow et al., 1996; Pentschew et al., 1963).

Ion channels, exchangers, and transporters represent important factors in the mechanism of cell volume regulation (for reviews, see Refs. Hoffmann and Dunham, 
1995; Mobasheri et al., 1998; O'Neill, 1999; Liang et al., 2007). Structural and functional changes in these systems may result in the loss of ion homeostasis (for a review, see Ref. Kintner et al., 2007) and the subsequent accumulation of intracellular water. These ion transporters and exchangers include the $\mathrm{Na}-\mathrm{K}-\mathrm{Cl}$ cotransporter (NKCC), volume-sensitive osmolyte anion channels, $\mathrm{Na}^{+} / \mathrm{Ca}^{2+}$ exchanger, the $\mathrm{Na}^{+} / \mathrm{H}^{+}$exchanger, and the nonselective cation channel ( $\left.\mathrm{NC}_{\mathrm{Ca}-\mathrm{ATP}}\right)$ (Liang et al., 2007). The NKCC1, in particular, has been shown to play an important role in the mediation of cell swelling/brain edema (for a review, see Ref. Chen and Sun, 2005). NKCC cotransporters are a class of membrane proteins that transport $\mathrm{Na}^{+}, \mathrm{K}^{+}$, and $\mathrm{Cl}^{-}$ions into and out of a wide variety of epithelial and nonepithelial cells and are part of a super family of cation-chloride cotransporters (Haas and Forbush, 2000). Two isoforms of NKCC have been identified (NKCC1 and NKCC2) (Xu et al., 1994; Haas and Forbush, 2000). NKCC1 is present in many cell types, including astrocytes (Tas et al., 1986; Tas et al., 1987; Walz, 1992; Plotkin et al., 1997; Su et al., 2000; Yan et al., 2001). The NKCC2 isoform is localized exclusively to the kidney (Ecelbarger et al., 1996; Payne and Forbush, 1994). NKCC1 activation was shown to contribute to astrocyte swelling/brain edema in ischemia and to brain edema after traumatic brain injury (MacVicar et al., 2002; Su et al., 2002a; Su et al., 2002b; Staub et al., 1994; Lu et al., 2006; Lu et al., 2007). Its role in astrocyte swelling after manganese treatment and in the brain edema in fulminant hepatic failure, however, is not known.

This study investigated whether NKCC activation occurs in manganese-treated astrocyte cultures and whether such activation contributes to astrocyte swelling. Our findings demonstrate that manganese increased NKCC activity, which was associated with an increase in total and phosphorylated NKCC1 protein expression. Blocking NKCC activity with bumetanide attenuated manganese-induced astrocyte swelling. Altogether, our findings suggest that activation of NKCC plays an important role in the mediation of manganese-induced astrocyte swelling and possibly in the brain edema associated with fulminant hepatic failure.

\section{MATERIALS AND METHODS}

\section{Astrocyte Cultures}

Astrocyte cultures were prepared from brains of 1-2 day old rat pups by the method of Ducis et al. (1990). Briefly, cerebral cortices were freed of meninges, minced, dissociated by trituration and vortexing, passed through sterile nylon sieves, placed in Dulbecco's modified Eagle's medium containing penicillin, streptomycin, and fetal bovine serum, and incubated at $37{ }^{\circ} \mathrm{C}$ in a humidified chamber provided with $5 \% \mathrm{CO}_{2}$ and $95 \%$ air. After 10 days in culture, bovine serum was replaced with $10 \%$ horse serum. After 14 days, cultures were treated and maintained with dibutyryl-cAMP (Sigma) so as to enhance cell differentiation (Juurlink and Hertz, 1985). Cultures consisted of at least $98 \%$ astrocytes, as determined by glial fibrillary acidic protein and glutamine synthetase immunocytochemistry. The remaining cells consisted of microglia. Experiments were carried out in 3-4 week old cells. Procedures followed guidelines established by the National Institutes of Health Guide for the care and use of laboratory animals and were approved by the local animal care committee (HSKCOP/IAEC, CLEAR/2010-11/1-11).

\section{NKCC Activity}

NKCC activity was measured as the bumetanidesensitive $\mathrm{K}^{+}$influx, using ${ }^{86} \mathrm{Rb}$ as a tracer for $\mathrm{K}^{+}$by a modification of the method of Sun and Murali (1999). Briefly, primary astrocyte cultures were treated once with a pathophysiological concentration of manganese (50 $\mu \mathrm{M})$. At the end of the treatment $(24 \mathrm{~h})$, cultures were equilibrated and preincubated with or without bumetanide $(50 \mu \mathrm{M})$ for $15-30 \mathrm{~min}$ at $37{ }^{\circ} \mathrm{C}$ in an isotonic HEPESminimal essential medium $(140 \mathrm{mM} \mathrm{NaCl}, 5.36 \mathrm{mM} \mathrm{KCl}$, $0.81 \mathrm{mM} \mathrm{MgSO}_{4}, 1.27 \mathrm{mM} \mathrm{CaCl}_{2}, 0.44 \mathrm{mM} \mathrm{KH}_{2} \mathrm{PO}_{4}, 0.33$ $\mathrm{mM} \mathrm{Na} \mathrm{HPO}_{4}, 5.55 \mathrm{mM}$ glucose, and $20 \mathrm{mM}$ HEPES $(300 \mathrm{mosM}))$. Cultures were then exposed to $1 \mu \mathrm{Ci} / \mathrm{ml}^{86} \mathrm{Rb}$ for $3 \mathrm{~min}$ and subsequently rinsed with ice-cold $0.1 \mathrm{M}$ $\mathrm{MgCl}_{2}$. Cells were then extracted in $1 \% \mathrm{SDS}$, and the radioactivity was analyzed by liquid scintillation. The ${ }^{86} \mathrm{Rb}$ influx rate was calculated by subtracting the influx (with bumetanide) from total influx (without bumetanide) and expressed as $\mathrm{nmol}$ of ${ }^{86} \mathrm{Rb} / \mathrm{mg}$ of protein $/ \mathrm{min}$. Quadruplicate determinations were obtained throughout the study, and the protein content was determined employing the BCA assay (Pierce).

\section{Cell Volume Determination}

Cell volume was estimated by measuring the intracellular water space by the method of Kletzien et al. (1975), as modified by Kimelberg (1987) and Bender and Norenberg (1998). Briefly, $1 \mathrm{mM}$ 3-O-methylglucose and $0.5 \mu \mathrm{Ci} / \mathrm{ml}^{3} \mathrm{H}$-labeled 3-O-methylglucose were added to the culture $6 \mathrm{~h}$ before the volume assay. At the end of the incubation period, culture medium was aspirated, and an aliquot was saved for radioactivity determination. Cells were rapidly washed six times with ice-cold buffer containing $229 \mathrm{mM}$ sucrose, $1 \mathrm{mM}$ Tris nitrate, $0.5 \mathrm{mM}$ calcium nitrate, and $0.1 \mathrm{mM}$ phloretin, pH7.4. Cells were then harvested into $0.5 \mathrm{ml}$ of $1 \mathrm{~N}$ sodium hydroxide. Radioactivity in the cell extracts and medium were determined, and an aliquot of the cell extract was used for protein estimation (BCA method). Values were normalized to protein level, and the cell volume was expressed as $\mu \mathrm{l} / \mathrm{mg}$ of protein.

\section{Western Immunoblots}

Astrocyte cultures were solubilized in lysis buffer (125 $\mathrm{mM}$ Tris- $\mathrm{HCl}, \mathrm{pH} 6.8,4 \%$ SDS, phosphatase inhibitors (Sigma), and a protease inhibitor mixture (Roche Applied Science), and protein levels were measured by the BCA method. Equal amounts of protein were subjected to gel electrophoresis, as previously described (Jayakumar et al., 2006), and transferred to nitrocellulose membranes. Following blocking with nonfat dry milk, membranes were incubated with respective antibodies. Total NKCC1 antibody was purchased from Chemicon International (Temecula, CA). Primary antibodies to detect phosphorylated (R5) and total NKCC1 were used at 1:1000. Anti-rabbit and anti-mouse horseradish peroxidase-conjugated secondary antibodies (Vector Laboratories) were used at 1:1000. Optical density of the bands were determined with the Chemi-Imager (Alpha Innotech, San Leandro, CA) digital imaging system, and the results were quantified with the Sigma Scan Pro (Jandell Scientific, San Jose, CA) program as a proportion of the signal of a housekeeping protein band ( $\beta$-actin).

Each experimental group consisted of 4-5 culture dishes/experiment for each time point studied in the cell 


\section{Ramakrishnan et al.,}

swelling experiments. At least 2-4 plates were used for Western blot analysis. All experiments were performed from 4-7 separate seedings. Data were subjected to ANOVA, followed by Tukey's post hoc comparisons. At each time point, the experimental cultures were compared with their respective controls.

\section{RESULTS}

Cell Volume Increased at Different Concentration of Manganese for 24 Hours

Manganese was treated at different concentrations for $24 \mathrm{~h}$. The cell volume increased at $20 \mu \mathrm{M}$ concentration and peaked at $50 \mu \mathrm{M}$ and persisted up to $100 \mu \mathrm{M}$ concentrations (Figure 1).

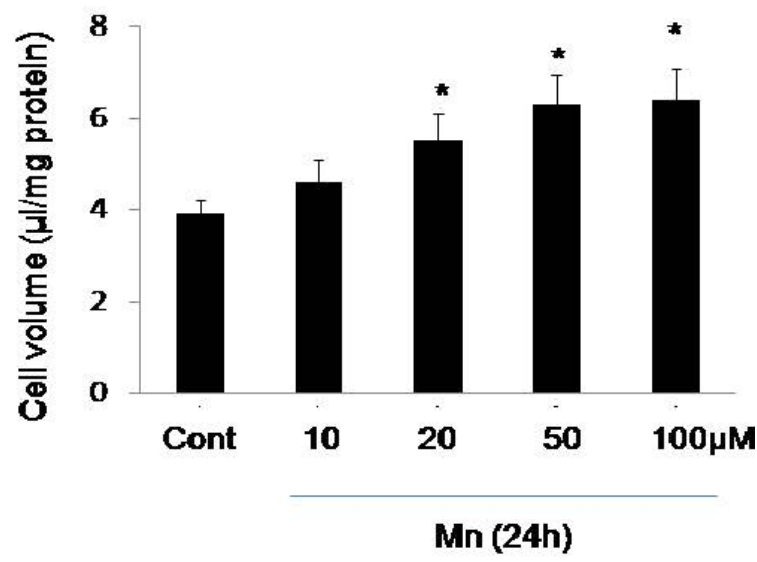

Figure 1: Manganese induced cell volume at different concentrations. Cultured astrocytes were exposed to different concentrations of manganese $(10,20,50$ and $100 \mu \mathrm{M}$ ) for 24 hours and the cell volume was measured. Manganese significantly increased cell volume at 20,50 and $100 \mu \mathrm{M}$. ANOVA, $\mathrm{n}=5 .{ }^{*} p<0.05$ vs. control. Error bars represent mean \pm SEM.

Cell Volume Increased at Different Time Period of Manganese Treatment (50 $\mu \mathrm{M})$

Manganese was treated for different time period with $50 \mu \mathrm{M}$ concentrations. The cell volume increased at $6 \mathrm{~h}$ and persisted up to $48 \mathrm{~h}$ with a peak increase at $24 \mathrm{~h}$ (Figure 2).

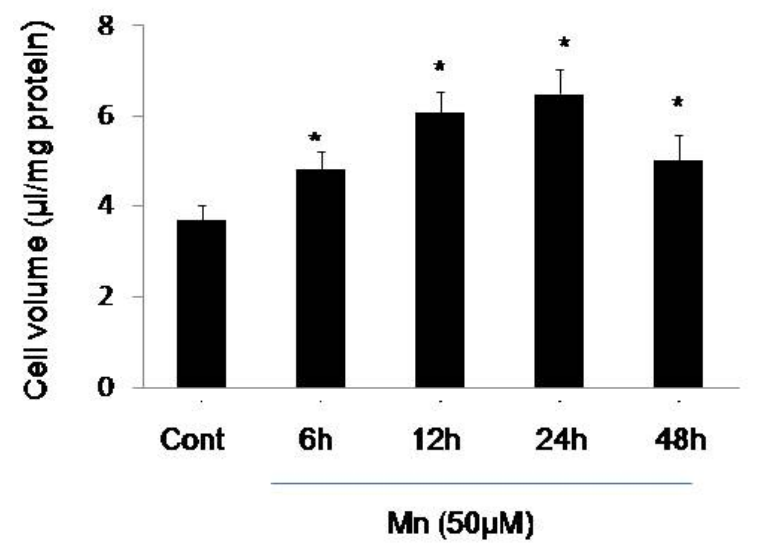

Figure 2: Manganese induced cell volume at different time periods. Astrocytes were exposed to manganese (50 $\mu \mathrm{M})$ for different time periods $(6,12,24$ and $48 \mathrm{~h}$ ). Manganese significantly increased the cell volume at all time points studied. However, there was a decline after 48 h. ANOVA, $n=4 .{ }^{*} p<0.05$ vs. control. Error bars represent mean \pm SEM.
Sci. Technol. Arts Res. J., Oct-Dec 2013, 2(4): 14-19

NKCC Activation by Manganese in Cultured Astrocytes

Manganese significantly increased NKCC activity. Initial increase was observed at $12 \mathrm{~h}$, which persisted up to $24 \mathrm{~h}$, with a peak increase occurring at $24 \mathrm{~h}$ (Figure 3).

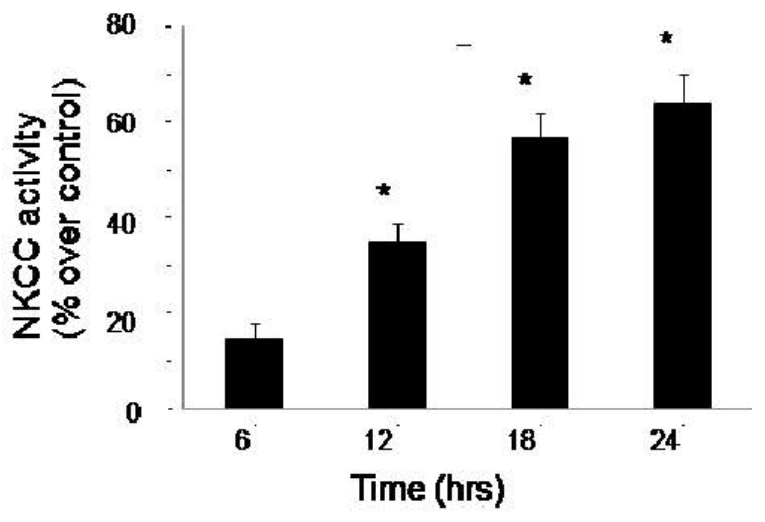

Figure 3: Manganese induced NKCC activity. Cultured astrocytes were exposed to $50 \mu \mathrm{M} \mathrm{Mn}$ for different time periods $(1-24 \mathrm{~h})$ and the bumetanide-sensitive NKCC activity was measured. Manganese significantly increased NKCC activity at 12,18 and $24 \mathrm{~h}$. ANOVA, $\mathrm{n}=5$. ${ }^{*} p<0.05$ vs. control. Error bars represent mean \pm SEM.

Treatment of Bumatenide Attenuated ManganeseInduced Astrocyte Swelling

Astrocyte cultures were exposed to manganese for 24 $\mathrm{h}$ with or without bumetanide $(50 \mu \mathrm{M})$, and cell volume was determined. The intracellular water space of control primary astrocytes culture was $4.2 \pm 0.1 \mu \mathrm{l} / \mathrm{mg}$ proteins. Cultures exposed to manganese showed a significant increase in cell volume $(39 \%$ as compared to control, $p<0.05)$. Cell swelling was significantly attenuated by treatment with $50 \mu \mathrm{M}$ bumetanide $(66 \%, p<0.05$ vs. control) (Figure 4).

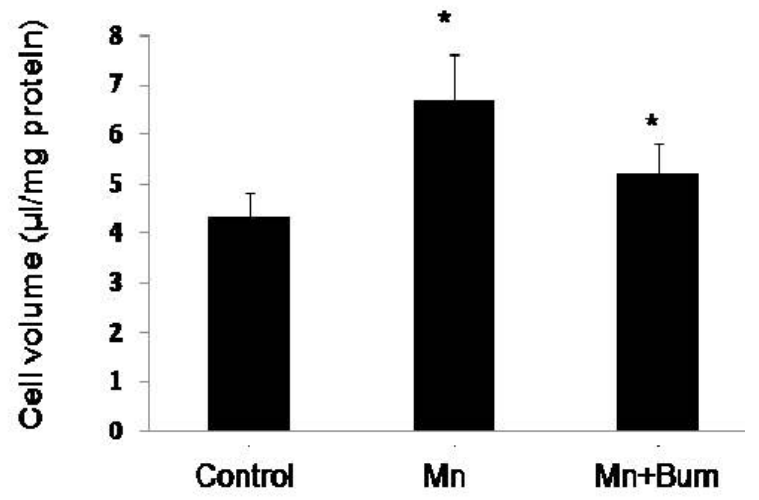

Figure 4: Effect of Bumatanide on astrocytes swelling. Cultured astrocytes exposed to $50 \mu \mathrm{M} M n$ significantly increased cell swelling $(54 \%)$ at $24 \mathrm{~h}$. Treatment with bumetanide (BUM, $50 \mu \mathrm{M})$ significantly diminished such swelling by $66 \%$. ANOVA, $n=5$. ${ }^{*} p<0.05$ vs. control. Error bars represent mean \pm SEM.

Manganese Increased NKCC1 Protein Expression

Cultures exposed to manganese significantly increased the total NKCC1 protein level as measured by Western blots. The initial increase was observed at $6 \mathrm{~h}$ and persisted for up to $24 \mathrm{~h}$ (Figure 5). 




Figure 5: Effect of Manganese on total NKCC1 protein level. Western blots show a significant increase in total NKCC1 protein level when cultures were exposed to $50 \mu \mathrm{M}$ Mn. NKCC1 levels were normalized against $\beta$ actin. ANOVA, $\mathrm{n}=5 .{ }^{*} p<0.05$ vs. control. Error bars represent mean \pm SEM.

Manganese Increased the Phosphorylation of NKCC1 Manganese also significantly increased the phosphorylation of NKCC1 at all time points (from $6 \mathrm{~h}$ to $24 \mathrm{~h})$. The cultures were treated with $50 \mu \mathrm{M}$ of Manganese at all time points (Figure 6).

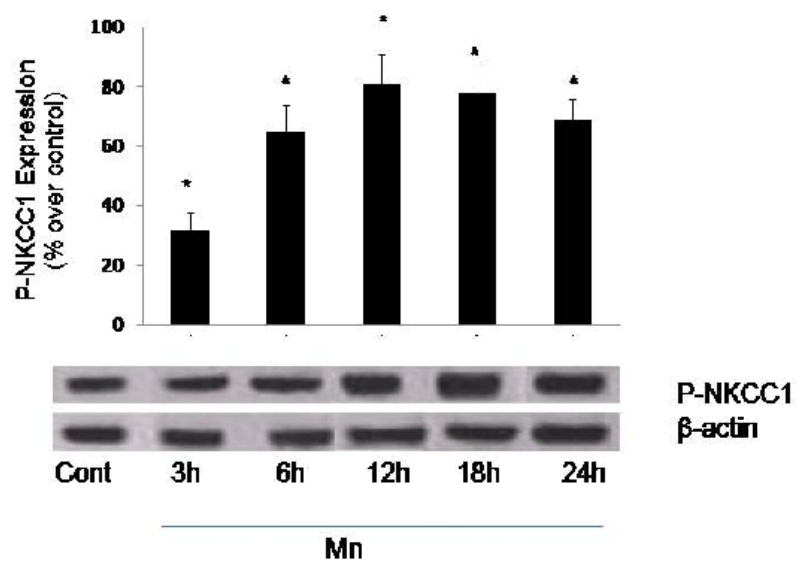

Figure 6: Effect of Manganese on Phosphorylated NKCC1 Expression. Western blots show a significant increase in phosphorylated NKCC1 (p-NKCC1) level when cultures were exposed to $50 \mu \mathrm{M}$ Manganese. Phospho-NKCC1 levels were normalized against $\beta$ actin. ANOVA, $n=6$. ${ }^{*} p<0.05$ vs. control. Error bars represent mean \pm SEM.

\section{DISCUSSION}

We have studied the role of $\mathrm{Na}-\mathrm{K}-\mathrm{Cl}$ cotransporter- 1 in the manganese induced astrocyte swelling. This study demonstrates the involvement of the ion transporter protein NKCC1 in the mechanism of manganese induced astrocyte swelling. Cultured astrocytes exposed to manganese increased the cell volume with the increase in time and concentrations. Manganese also increased the bumetanide sensitive NKCC activity as well as total and phosphorylated (activated) NKCC1. Blocking NKCC activation with bumetanide diminished manganeseinduced cell swelling. These findings suggest that manganese-induced activation of NKCC1 is an important factor in the mediation of cell swelling in cultured astrocytes, and that such activation appears to be mediated by phosphorylation of NKCC1.

NKCC is involved in the regulation of several cellular functions, including ion transport across secretory and absorptive epithelia (for reviews, see ref. Haas, 1994), $\mathrm{NH}_{4}{ }^{+}$transport (Nagaraja and Brooks, 1998), maintenance and regulation of cell volume and ion gradients (for reviews see ref. Kaplan et al., 1996). The electroneutral NKCC protein transports $\mathrm{Na}^{+}, \mathrm{K}^{+}$, and $\mathrm{Cl}^{-}$ into cells under both physiological and pathophysiological conditions with a stoichiometry of $1 \mathrm{Na}^{+}: 1 \mathrm{~K}^{+}: 2 \mathrm{Cl}^{-}$(for review, see ref. Haas and Forbush, 1998). NKCC can be inhibited by either bumetanide or furosemide (Kimmelberg and Frangakis, 1985; Russell, 2000). NKCC1 is present in many cell types, including astrocytes (Yan et al., 2001; Hoppe and Kettenmann, 1989; Wang et al., 2003; Alvarez-Leefmans, 2001). However, the NKCC2 isoform is localized exclusively to the kidney (Ecelbarger et al., 1996; Payne and Forbush, 1994). Activation of NKCC has been shown to cause brain edema in several neurological disorders. A recent study showed that administration of bumetanide, either prior to or during ischemia, significantly reduces brain edema in rats (Yan et al., 2001). Activation of NKCC1 was shown to contribute to brain edema after traumatic brain injury (Staub et al., 1994; Lu et al., 2006; Lu et al., 2007).

NKCC1 plays an important role in cell volume regulation in brain astrocytes (Su et al., 2002a; Su et al., 2002b; Chen and Sun, 2005). The cotransporter activity in astrocytes is significantly stimulated in response to high $\mathrm{K}^{+}$in a Ca ${ }^{2+}$ dependent manner ( $\mathrm{Su}$ et al., 2000). Stimulation of NKCC1 by high $\mathrm{K}^{+}$results in cell swelling through a net increase of intracellular $\mathrm{Na}^{+}, \mathrm{K}^{+}, \mathrm{Cl}^{-}$and accompanying water. Recently, Su et al. (2002) showed that inhibition of NKCC by bumetanide abolishes high extracellular $\mathrm{K}^{+}$-induced swelling and intracellular $\mathrm{Cl}^{-}$ accumulation in rat cortical astrocytes. These authors also showed that astrocytes from NKCC1 cotransporter-null mice exhibit an absence of swelling. Consistent with these findings, our study shows that astrocyte cultures exposed to manganese caused a significant increase in bumetanide-sensitive NKCC activity and that blocking such activity significantly reduced manganese-induced astrocyte swelling. These findings indicate the involvement of NKCC1 in the mechanism of astrocyte swelling following manganese exposure. Activation of NKCC1 results in the accumulation of sodium inside the cell and such increase in $\left[\mathrm{Na}^{+}\right] \mathrm{i}$ may cause cellular swelling (Xie et al., 1994). An increase in $[\mathrm{Na}+] \mathrm{i}$ concentration due to increased NKCC1 activity was observed in rat cortical astrocytes after chemical hypoxia and in rat spinal cord astrocytes after glucose deprivation (Rose et al., 1998); and in mouse cortical astrocytes after ischemia (Silver et al., 1997). NKCC1-mediated intracellular $\mathrm{Na}+$ accumulation and cell swelling was also observed in astrocytes exposed to oxygen and glucose deprivation/reoxygenation, and such increase was diminished by bumetanide (Lenart et al., 2004).

Phosphorylation of NKCC1 has been shown to activate its activity (Lyte and Forbush, 1992). Phosphorylation of Thr184/Thr189 correlates with NKCC1 activation in epithelial cells (Darman and Forbush, 2002). 


\section{Ramakrishnan et al.,}

Such a correlation has also been found in cultured cortical neurons (Schomberg et al., 2003). Our study demonstrates that manganese results in the phosphorylation (activation) of NKCC1. We also found a significant increase in total NKCC1 protein level after manganese treatment. Studies have shown that reduced NKCC1 protein expression diminish NKCC activity when bovine brain microvessel endothelial cells are exposed to hypoxia/aglycemia (Abbruscato et al., 2004). Taken together, these studies indicate that manganese causes an increase in both total and phosphorylated NKCC1 and that such increase was associated with its enhanced activity.

\section{CONCLUSION}

Our study reveals that NKCC1 is involved in the mediation of manganese-induced astrocyte swelling, and that phosphorylation of NKCC1 contributes to such activation. Targeting NKCC1 may provide a useful strategy in the treatment of the brain edema associated with fulminant hepatic failure.

\section{REFERENCES}

Abbruscato, T.J., Lopez, S.P., Roder, K., Paulson, J.R. (2004). Regulation of blood-brain barrier $\mathrm{Na}, \mathrm{K}, 2 \mathrm{Cl}$ cotransporter through phosphorylation during in vitro stroke conditions and nicotine exposure. Journal of Pharmacoogy and Experimental Therapeutics 310: 459468

Alvarez-Leefmans, F.J. (2001). Intracellular chloride regulation. In: Cell Physiology Sourcebook: A Molecular Approach (Sperelakis, N., ed.), pp. 301-318. Academic Press, San Diego.

Aschner, M., Gannon, M., Kimelberg, H.K. (1992). Manganese uptake and efflux in cultured rat astrocytes. Journal of Neurochemistry 58: 730-735.

Aschner, M., Vrana, K.E., Zheng, W. (1999). Manganese uptake and distribution in the central nervous system (CNS). Neurotoxicology 20: 173-180.

Bender, A.S., Norenberg, M.D. (1998). Effect of benzodiazepines and neurosteroids on ammonia-induced swelling in cultured astrocytes. Journal of Neuroscience Research 54: 673-680.

Chen, H., Sun, D. (2005). The role of Na-K-Cl co-transporter in cerebral ischemia. Neurological Research 27: 280-286.

Darman, R. B., Forbush, B. (2002). A regulatory locus of phosphorylation in the $\mathrm{N}$ terminus of the $\mathrm{Na}-\mathrm{K}-\mathrm{Cl}$ cotransporter, NKCC1. Journal of Biological Chemistry 277: 37542-37550.

Ducis, I., Norenberg, L.O.B., Norenberg, M.D. (1990). The benzodiazepine receptor in cultured astrocytes from genetically epilepsy-prone rats. Brain Research 531: 318321.

Ecelbarger, C.A., Terris, J., Hoyer, J.R., Nielsen, S., Wade, J. B., Knepper, M.A. (1996). Localization and regulation of the rat renal $\mathrm{Na}(+)-\mathrm{K}(+)-2 \mathrm{Cl}-$ cotransporter, BSC-1. American Journal of Physioogy 271: F619-F628.

Haas, M. (1994). The Na-K-Cl cotransporters. American Journal of Physiology 267: C869-885.

Haas, M., Forbush, B., $3^{\text {rd }}$ (1998). The Na-K-Cl co transporters. Journal of Bioenergy and Biomembrane 30: 161-172.
Sci. Technol. Arts Res. J., Oct-Dec 2013, 2(4): 14-19

Haas, M., Forbush, B., III (2000). The Na-K-Cl cotransporter of secretory epithelia. Annual Review of Physiology 62: 515-534.

Hoffmann, E.K., Dunham, P.B. (1995). Membrane mechanisms and intracellular signalling in cell volume regulation. Internal Review of Cytology 161: 173-262.

Hoppe, D., Kettenmann, H. (1989). GABA triggers a Cl- efflux from cultured mouse oligodendrocytes. Neuroscience Letters 97: 334-339.

Jayakumar, A.R., Panickar, K.S., Murthy, C.R.K., Norenberg, M. D. (2006). Oxidative stress and mitogen-activated protein kinase phosphorylation mediate ammonia-induced cell swelling and glutamate uptake inhibition in cultured astrocytes. Journal of Neuroscience 26: 4774-4784.

Juurlink, B.H., Hertz, L. (1985). Plasticity of astrocytes in primary cultures: an experimental tool and a reason for methodological caution. Developmental Neuroscience 7: 263-277.

Kaplan, M.R., Mount, D.B., Delpire, E. (1996). Molecular mechanisms of $\mathrm{NaCl}$ cotransport. Annual Review of Physiology 58: 649-668.

Kimmelberg, H.K., Frangakis, M.V. (1985). Furosemide- and bumetanide-sensitive ion transport and volume control in primary astrocyte cultures from rat brain. Brain Research 361: 125-134

Kimelberg, H. K. (1987). Anisotonic media and glutamateinduced ion transport and volume responses in primary astrocyte cultures. Journal of Physiology 82: 294-303.

Kintner, D. B., Wang, Y., Sun, D. (2007). Role of membrane ion transport proteins in cerebral ischemic damage. Frontier Bioscience 12: 762-770.

Kletzein, R.F., Pariza, M.W., Becker, J.E., Potter V.R. (1975). A method using 3-O-methyl-D-glucose and phloretin for the determination of intracellular water space of cells in monolayer culture. Annals Biochemistry 68: 537-544.

Lenart, B., Kintner, D.B., Shull, G.E., Sun, D. (2004). Na-K-CI cotransporter-mediated intracellular $\mathrm{Na}^{+}$accumulation affects $\mathrm{Ca}^{2+}$ signaling in astrocytes in an in vitro ischemic model. Journal of Neuroscience 24: 9585-9597.

Liang, D., Bhatta, S., Gerzanich, V., Simard, J. M. (2007). Cytotoxic edema: mechanisms of pathological cell swelling. Neurosurgery Focus 22: E2.

Lu, K.T., Wu, C.Y., Cheng, N.C., Wo, Y.Y., Yang, J.T., Yen, H.H., Yang, Y.L. (2006). Inhibition of the $\mathrm{Na}+-\mathrm{K}+-2 \mathrm{Cl}-$ cotransporter in choroid plexus attenuates traumatic brain injury-induced brain edema and neuronal damage. European Journal of Pharmacology 548: 99-105.

Lu, K.T., Wu, C.Y., Yen, H.H., Peng, J.H., Wang, C.L., Yang, Y.L. (2007). Bumetanide administration attenuated traumatic brain injury through IL-1 overexpression. Neurology Research 29: 404-409.

Lytle, C., Forbush, B. (1992). The Na-K-Cl cotransport protein of shark rectal gland. II. Regulation by direct phosphorylation. Journal of Biological Chemistry 267: 25438-25443.

MacVicar, B. A., Feighan, D., Brown, A., Ransom, B. (2002). Intrinsic optical signals in the rat optic nerve: role for $\mathrm{K}(+)$ uptake via NKCC1 and swelling of astrocytes. Glia 37: 114-123.

Martinez, A. J. (1968). Electron microscopy in human hepatic encephalopathy. Acta Neuropathologica (Berl.) 11: 82-86. 
Ramakrishnan et al.,

McCord, J.M. (1976). Iron- and manganese-containing superoxide dismutases: structure, distribution, and evolutionary relationships. Advanced Experimental Medicine and Biology 74: 540-550.

Mobasheri, A., Mobasheri, R., Francis, M.J., Trujillo, E., Alvarez, de la Rosa, D., Martín-Vasallo, P. (1998). Ion transport in chondrocytes: membrane transporters involved in intracellular ion homeostasis and the regulation of cell volume, free $\left[\mathrm{Ca}^{2+}\right]$ and $\mathrm{pH}$. Histology and Histopathology 13: 893-910.

Nagaraja, T.N., Brookes, N. (1998). Intracellular acidification induced by passive and active transport of ammonium ions in astrocytes. American Journal of Physiology 274: C883-C891.

Norenberg, M.D. (1977). A light and electron microscopic study of experimental portal-systemic (ammonia) encephalopathy. Progression and reversal of the disorder. Laboratory Investigation 36: 618-627.

Norenberg, M.D. (2001). Astrocytes and ammonia in hepatic encephalopathy. In: Astrocytes in the aging brain (de Vellis J, ed.) pp. 477-496. Totowa, NJ: Humana.

Olanow, C.W., Good, P.F., Shinotoh, H., Hewitt, K.A., Vingerhoets, F., Snow, B.J., Beal, M.F., Calne, D.B., Perl, D.P. (1996). Manganese intoxication in the rhesus monkey: a clinical, imaging, pathologic, and biochemical study. Neurology 46: 492-498.

O'Neill, W. C. (1999). Physiological significance of volumeregulatory transporters. American Journal of Physiology 276: C995-C1011.

Payne, J.A., Forbush, B. III (1994). Alternatively spliced is oforms of the putative renal $\mathrm{Na}-\mathrm{K}-\mathrm{Cl}$ cotransporter are differentially distributed within the rabbit kidney. Proceedings of National Academy of Sciences U. S. A 91: 4544-4548.

Pentschew, A., Ebner, F.F., Kovatch, R.M. (1963). Experimental manganese encephalopathy in monkeys. A preliminary report. Journal of Neuropathology and Experimental Neurology 22: 488-499.

Plotkin, M.D., Kaplan, M.R., Peterson, L.N., Gullans, S.R., Hebert, S.C., Delpire, E. (1997). Expression of the $\mathrm{Na}(+)$ $\mathrm{K}(+)-2 \mathrm{Cl}$ - cotransporter BSC2 in the nervous system. American Journal of Physiology 272: C173-C183.

Rama Rao, K.V., Reddy, P.V.B., Hazell, A.S., Norenberg, M. D. (2007). Manganese induces cell swelling in cultured astrocytes. Neurotoxicology 28: 807-812.

Rose, C.R., Waxman, S.G., Ransom, B.R. (1998). Effects of glucose deprivation, chemical hypoxia, and simulated ischemia on $\mathrm{Na}^{+}$homeostasis in rat spinal cord astrocytes. Journal of Neuroscience 18: 3554-3562.

Russell, J.M. (2000). Sodium-potassium-chloride cotransport. Physiological Review 80: 211-276.

Schomberg, S.L., Bauer, J., Kintner, D.B., Su, G., Flemmer, A., Forbush, B., Sun, D. (2003). Cross talk between the GABA(A) receptor and the $\mathrm{Na}-\mathrm{K}-\mathrm{Cl}$ cotransporter is mediated by intracellular $\mathrm{Cl}^{-}$. Journal of Neurophysiology 89: 159-167.

Silver, I. A., Deas, J., Erecinska, M. (1997). Ion homeostasis in brain cells: differences in intracellular ion responses to energy limitation between cultured neurons and glial cells. Neuroscience 78: 589-601.
Sci. Technol. Arts Res. J., Oct-Dec 2013, 2(4): 14-19

Staub, F., Stoffel, M., Berger, S., Eriskat, J., Baethmann, A. (1994). Treatment of vasogenic brain edema with the novel Cl- transport inhibitor torasemide. Journal of Neurotrauma 11: 679-690.

Su, G., Haworth, R.A., Dempsey, R.J., Sun, D. (2000). Regulation of $\mathrm{Na}(+)-\mathrm{K}(+)-\mathrm{Cl}(-)$ cotransporter in primary astrocytes by dibutyryl cAMP and high $[\mathrm{K}(+)](0)$. American Journal of Physiology and Cell Physiology 279: C1710C1721.

Su, G., Kintner, D.B., Sun, D. (2002a). Contribution of $\mathrm{Na}(+)-$ $\mathrm{K}(+)-\mathrm{Cl}(-)$ cotransporter to high-[K(+)](0)- induced swelling and EAA release in astrocytes. American Journal of Physiology and Cell Physiology 282: C1136-C1146.

Su, G., Kintner, D.B., Flagella, M., Shull, G.E., Sun, D. (2002b). Astrocytes from $\mathrm{Na}(+)-\mathrm{K}(+)-\mathrm{Cl}(-)$ cotransporternull mice exhibit absence of swelling and decrease in EAA release. American Journal of Physiology and Cell Physiology 282: C1147-C1160.

Sun, D., Murali, S.G. (1999). Na+-K+-2Cl- cotransporter in immature cortical neurons: A role in intracellular $\mathrm{Cl}$ regulation. Journal of Neurophysiology 81: 1939-1948.

Tas, P.W., Massa, P.T., Koschel, K. (1986). Preliminary characterization of an $\mathrm{Na}+, \mathrm{K}+, \mathrm{Cl}$ - co-transport activity in cultured human astrocytes. Neuroscience Letters 70: 369373 .

Tas, P.W., Massa, P.T., Kress, H.G., Koschel, K. (1987). Characterization of an $\mathrm{Na}+/ \mathrm{K}+/ \mathrm{Cl}$ - co-transport in primary cultures of rat astrocytes. Biochimica Biophysica Acta 903: 411-416.

Traber, P., DalCanto, M., Ganger, D., Blei, A.T. (1989). Effect of body temperature on brain edema and encephalopathy in the rat after hepatic devascularization. Gastroenterology 96: 885-891.

Vaquero, J., Chung, C., Blei, A.T. (2003). Brain edema in acute liver failure. A window to the pathogenesis of hepatic encephalopathy. Annals of Hepatology 2: 12-22.

Walz, W. (1992). Role of $\mathrm{Na} / \mathrm{K} / \mathrm{Cl}$ cotransport in astrocytes. Canadian Journal of Physiology and Pharmacology 70: 260-262.

Wang, H., Yan Y., Kintner, D.B., Lytle, C., Sun, D. (2003). GABA-mediated trophic effect on oligodendrocytes requires $\mathrm{Na}-\mathrm{K}-2 \mathrm{Cl}$ cotransport activity. Journal of Neurophysiology 90: 1257-1265.

Wedler, F.C., Denman, R.B., Roby, W.G. (1982). Glutamine synthetase from ovine brain is a manganese(II) enzyme. Biochemistry 21: 6389-6396.

Xie, Y., Dengler, K., Zacharias, E., Wilffert, B., Tegtmeier, F. (1994). Effects of the sodium channel blocker tetrodotoxin (TTX) on cellular ion homeostasis in rat brain subjected to complete ischemia. Brain Research 652: 216-224.

Xu, J.C., Lytle, C., Zhu, T.T., Payne, J.A., Benz, E. Jr., Forbush, B. $3^{\text {rd }}$ (1994). Molecular cloning and functional expression of the bumetanide sensitive $\mathrm{Na}-\mathrm{K}-\mathrm{Cl}$ cotransporter. Proceedings of National Academy of Sciences, U. S. A 91: 2201-2205.

Yan, Y., Dempsey, R.J., Sun, D. (2001). Expression of $\mathrm{Na}$ $(+)-\mathrm{K} \quad(+)-\mathrm{Cl}(-)$ cotransporter in rat brain during development and its localization in mature astrocytes. Brain Research 911: 43-55. 